\title{
Functional extruded snacks with lycopene and soy protein
}

\author{
Snacks extrusados funcionais com licopeno e proteína de soja
}

\author{
Paula Fernanda Pinto DA COSTA², Mariano Bueno Marcondes FERRAZ², Valquíria ROS-POLSKI ${ }^{2}$, \\ Ernesto QUAST ${ }^{1}$, Fernanda Paula COLLARES QUEIROZ², Caroline Joy STEEL ${ }^{2 *}$
}

\begin{abstract}
In this work, the effects of thermoplastic extrusion process parameters (raw material moisture content and temperature) and the addition of functional ingredients (lycopene and soy protein) on quality characteristics of a base-formulation for extruded corn snacks were studied, with the objective of developing an easy-to-eat functional product. A single-screw Labor PQ 30 model Inbramaq extruder was used for extrusion and a central composite rotational design (CCRD) was followed. The independent variables were: i) percentage of soy protein isolate $(0-30 \%)$; ii) percentage of lycopene preparation (0-0.1\%); iii) raw material moisture content $(20-30 \%)$; and iv) $5^{\text {th }}$ zone temperature (100-150 $\left.{ }^{\circ} \mathrm{C}\right)$. The expansion index reached maximum values with the lowest raw material moisture content (20\%) and intermediate temperatures (approximately $125^{\circ} \mathrm{C}$ ). Instrumental hardness was higher with high moisture and low temperature; however, increasing the percentage of soy protein was beneficial for the texture of the product, reducing hardness. The red color intensity increased with the increase in lycopene content and moisture, and with the reduction of temperature. Sensory acceptance tests were carried out for two products, with maximum percentages of the functional ingredients, $20 \%$ moisture and temperatures of 125 and $137^{\circ} \mathrm{C}$, with greater acceptance for the product extruded at $125^{\circ} \mathrm{C}$. Keywords: snacks; extrusion; functional foods; lycopene; soy protein isolate.
\end{abstract}

\section{Resumo}

Neste trabalho, estudou-se a influência de parâmetros do processo de extrusão termoplástica (umidade da matéria-prima e temperatura) e da adição de ingredientes funcionais (licopeno e proteína de soja) sobre características de qualidade de uma formulação-base para snacks extrusados de milho, com o objetivo de desenvolver um alimento funcional de fácil consumo. Utilizou-se um extrusor monorrosca Inbramaq, modelo Labor PQ 30, e seguiu-se um planejamento experimental com as seguintes variáveis independentes: i) teor de isolado proteico de soja (0 a 30\%); ii) teor de preparado de licopeno (0 a $0,1 \%)$; iii) umidade da matéria-prima (20 a $30 \%$ ); e iv) temperatura do extrusor na zona $5\left(100\right.$ a $\left.150{ }^{\circ} \mathrm{C}\right)$. O índice de expansão atingiu valores máximos com o menor valor de umidade da matéria-prima (20\%) e temperatura intermediária (aproximadamente $125^{\circ} \mathrm{C}$ ). A dureza instrumental foi mais elevada com umidade alta e temperatura baixa, entretanto, $\mathrm{o}$ aumento do teor de proteína de soja foi benéfico para a textura do produto final, reduzindo a dureza. A intensidade da coloração vermelha aumentou com o aumento do teor de licopeno e da umidade, e com a diminuição da temperatura. Foram realizados testes de aceitação sensorial para dois produtos, com os teores máximos dos ingredientes funcionais, $20 \%$ umidade e temperaturas de 125 e $137^{\circ} \mathrm{C}$, obtendo-se maior aceitação para o produto extrusado a $125^{\circ} \mathrm{C}$.

Palavras-chave: snacks; extrusão; alimentos funcionais; licopeno; isolado proteico de soja.

\section{Introduction}

Extruded foods such as snacks have become part of the dietary habits of a great part of the population. They can be prepared with ingredients or components that give them specific functional properties (HUANG et al., 2006; IBANOGLU et al., 2006; REID, 1998).

Extrusion cooking technology has been widely used in the production of snacks, due to technological advances in this area when compared to traditional food processing techniques (WHITE, 1994). This technology is also employed to produce breakfast cereals, toast, pet food, pasta and plastic materials. Extruders are used to heat and also to mold products, functioning as reactors, modifying final product characteristics.
Extrusion cooking, particularly for snack production, is a complex process that differs from the conventional process as it involves high shear and high temperatures $\left(\right.$ above $150{ }^{\circ} \mathrm{C}$ ) during a short period of time (seconds) (ATHAR et al., 2006). The thermal energy generated by vapor dissipation during extrusion, combined with the effect of shear, rapidly cooks and modifies the properties of the ingredients. Many thermomechanical processes are involved, including the Maillard reaction, protein denaturation, hydrolysis and expansion (THYMI et al., 2005).

Physical characteristics of snacks, such as expansion, hardness and density, are important parameters that affect consumption and acceptability of the final products, as well as

Recebido para publicação em 25/3/2008

Aceito para publicação em 4/1/2009 (003298)

${ }^{1}$ Departamento de Descentralização do Desenvolvimento, PRDTA Sudoeste Paulista, Agência Paulista de Tecnologia dos Agronegócios - APTA, Capão Bonito - SP, Brasil

2 Departamento de Tecnologia de Alimentos, Universidade Estadual de Campinas - UNICAMP, Campinas - SP, Brasil, E-mail: cjsteel@yahoo.com

${ }^{*}$ A quem a correspondência deve ser enviada 
their technological functional characteristics (JAMORA; RHEE; RHEE, 2001; LAUNAY; LISCH, 1983; TAHNOVEN et al., 1998; THYMI et al., 2005; WAGNER, 1989).

Various studies have been carried out on the enrichment of snacks with different ingredients, such as soy flour (LI et al., 2005; NWABUEZE, 2007), soy protein isolate (LEE; BRENNAND, 2005; VERÔNICA; OLUSOLA; ADEBOWALE, 2006), tomato powder (HUANG et al., 2006; IBANOGLU et al., 2006), vitamins (ATHAR et al., 2006), carrot and basil powder (IBANOGLU et al., 2006), yam flour (ALVES; GROSSMANN, 2002), among other ingredients, such as oats and fibers (BOMBO, 2006; KARAM; GROSSMANN; SILVA, 2001).

Soybean has been identified as a good source of protein and its consumption has increased with the knowledge brought by research that points out the health benefits of this seed (LEE; BRENNAND, 2005). Most of the beneficial effects come from the protein fraction, as recent studies demonstrate (DESROCHES, 2004; LOVATI; MANZONI; GIANAZZA, 2000). Soy protein reduces levels of cholesterol in blood plasma in individuals with high cholesterol levels, reducing the risk of cardiac diseases. It also acts to reduce the risk of breast and prostate cancers and increases bone density, due to the presence of isoflavones and other phytochemicals (DESROCHES, 2004; LI et al., 2005; LOVATI; MANZONI; GIANAZZA, 2000).

In October 1999, the FDA approved the use of the health claim: "Soybean can reduce the risk of cardiac disease" on the labels of soybeans and products containing soybeans. The following variation may also be used: "Diets with a low ingestion of saturated fat and cholesterol that include $25 \mathrm{~g}$ soy protein daily, can reduce the risk of cardiac disease" (LI et al., 2005).

The addition of soy protein to extruded products increases protein content, increasing nutritional value. During extrusion, the enzyme lipoxygenase, responsible for the soybean flavor in food products, is inactivated. Other consequences of the addition of soy protein are reduced expansion and increased hardness (LI et al., 2005; VERÔNICA; OLUSOLA; ADEBOWALE, 2006).

Another ingredient that has recently become more important in the enrichment of snacks is tomato, used in powder form, especially as it is rich in carotenoids, specifically lycopene, a potent antioxidant (HUANG et al., 2006).

Lycopene is a carotenoid present in red tomatoes, appreciated for its beneficial effects. The capacity of lycopene to act as a potent antioxidant is related to its potential to protect cells against oxidative damage, thus, reducing the risk of chronic diseases. Lycopene has also been demonstrated to induce cell to cell communication, to regulate hormones, the immune system and other chemical reactions in the human metabolism (HUANG et al., 2006).

Its ingestion comes from the consumption of tomato sauce or juice, fresh tomato and other foods that contain tomato as an ingredient. Studies have demonstrated that lycopene is resistant to high temperatures, and these actually improve its bioavailability (GOULA et al., 2006). Other forms of ingestion are the synthetic compounds that exist on the market, which can be added to the formulation of different products or consumed in the form of dietary supplements, such as capsules. Various studies have been carried out, evaluating the action of lycopene in the reduction of the risks of diseases such as prostate cancer. The dosages used vary from $1.5 \mathrm{mg} /$ day to $20 \mathrm{mg} /$ day, but studies show that the ingestion of $6.46 \mathrm{mg} /$ day is effective to reduce the risk of cancer (GANN et al., 1999; GIOVANNUCCI et al., 1995).

According to the Brazilian National Health Surveillance Agency, ANVISA (2008), the declaration on labels of foods containing lycopene should contain the phrase: "Lycopene has antioxidant activity that protects cells against free radicals. Its consumption must be associated with a balanced diet and a healthy lifestyle". The quantity of lycopene in a daily portion of the product in its ready-to-eat form must be declared on the label, close to the health claim (ANVISA, 2003, 2008).

The incorporation of ingredients with functional characteristics to snacks is an alternative to add nutrients and/ or compounds that are beneficial to health, normally found in vegetables or other products which are more difficult to consume in their natural form by children and people with a busy working life, with irregular dietary habits.

Therefore, the objective of this work was to study the influence of parameters of the thermoplastic extrusion process (raw material moisture content and temperature) and of the addition of functional ingredients (lycopene and soy protein) on quality characteristics of a base-formulation for corn extruded snacks. A complete factorial experimental design was followed and the results were analyzed through the Response Surface Methodology to identify the best conditions.

\section{Materials and methods}

\subsection{Raw materials}

The raw materials used in this work were: i) corn flour (Baptistella Alimentos, Itatiba - SP, Brazil); ii) powder lycopene preparation Lycovit $10 \mathrm{CWD}$, containing $10 \%$ lycopene (BASF, São Paulo/SP, Brazil); and iii) soy protein isolate (SPI), containing minimum $90 \%$ protein (Solae Alimentos, São Paulo/ SP, Brazil).

\subsection{Characterization of the raw materials}

Corn flour and SPI were characterized with respect to their particle size distribution through AOAC Method 965.22 (AOAC, 1995), using a Produtest set of sieves (20, 35, 60, 80, 100 mesh and bottom), and with respect to their proximate composition following AACC Method 44-15A for moisture, AACC Method 46-13 (micro-Kjeldahl) for proteins, AACC Method 30-10 for lipids and AACC Method 08-01 for ash (AACC, 1983). Carbohydrates were determined by difference.

\subsection{Conditioning, extrusion and drying}

Before extrusion, each assay was conditioned to the moisture content level determined by the experimental design. This step was carried out knowing the initial moisture content of the corn flour and SPI mixture, and calculating the quantity of water 
necessary to reach the desired final moisture content. Lycopene was then diluted in this volume of water, and the solution was slowly added to the dry mixture, in drops, while homogenizing in a planetary mixer (GE, USA). After complete homogenization, samples were packed in polyethylene plastic bags and stored under refrigeration, at $4{ }^{\circ} \mathrm{C}$, for 24 hours, to balance moisture.

For extrusion, a single-screw extruder, model Labor PQ 30 (Inbramaq, Ribeirão Preto/SP, Brazil), was used, with the following fixed parameters: i) vibration ramp at $45 \%$; ii) main motor at $90 \%$ rotation capacity; iii) motor amperage varying between 12.5 and 13.0 A; iv) cylinder-shaped screw, with 2 crests; v) barrel temperature in zone 1: $25^{\circ} \mathrm{C}$; vi) barrel temperature in zone $2: 50{ }^{\circ} \mathrm{C}$; vii) barrel temperature in zone 3: $75^{\circ} \mathrm{C}$; viii) barrel temperature in zone $4: 100^{\circ} \mathrm{C}$; and ix) die diameter: $3 \mathrm{~mm}$.

After extrusion, the products were dried in an oven at $70^{\circ} \mathrm{C}$ for 2 hours.

\subsection{Experimental design}

A $2^{4}$ complete factorial experimental design was used, with the following independent variables: i) SPI addition (0 to 30\%); ii) lycopene preparation addition (0 to $0.100 \%$ ); iii) raw material moisture content (20 to $30 \%$ ); and iv) barrel temperature in zone 5 (100 to $\left.150{ }^{\circ} \mathrm{C}\right)$.

To establish the levels of lycopene preparation, the following information was considered: its lycopene concentration (10\%), USDA lycopene consumption recommendation $(6.46 \mathrm{mg} /$ day $)$ (GANN et al., 1999; GIOVANNUCCI et al., 1995) and the snack portion established by ANVISA (25 g) (ANVISA, 2003). The limits were defined to include snack portions that would supply $25 \%$ of the USDA recommendation. Using $0.100 \%$ of the commercial product with $10 \%$ lycopene as upper limit, $2.5 \mathrm{mg}$ lycopene per $25 \mathrm{~g}$ portion of snack are obtained, which corresponds to $38.7 \%$ of the recommended daily ingestion.

The levels of SPI used were established considering: its minimum protein concentration (90\%), the FDA's RDI (recommended daily ingestion) for soy protein ( $25 \mathrm{~g} /$ day) (FDA, 2000) and the snack portion established by ANVISA (25 g) (ANVISA, 2003). The limits were defined to include snack portions that would supply $25 \%$ of ANVISA's recommendation. Using 30\% SPI with $90 \%$ soy protein as upper limit, $6.75 \mathrm{~g}$ soy protein per $25 \mathrm{~g}$ snack portion are obtained, which corresponds to $27 \%$ of the RDI.

The levels of the independent variables are presented in Table 1.

The complete matrix of the experimental design used is presented together with the results of the characterization of the extruded products (Table 3 ).

\subsection{Characterization of the extruded products}

The extruded products were characterized as to their expansion index (EI), instrumental hardness and instrumental color.
Table 1. Levels of the independent variables.

\begin{tabular}{lccccc}
\hline \multicolumn{1}{c}{ Independent variables } & $-\alpha(-2)$ & -1 & 0 & +1 & $+\alpha(+2)$ \\
\hline SPI $(\%)^{1}$ & 0.0 & 7.5 & 15.0 & 22.5 & 30.0 \\
Lycopene $(\%)^{2}$ & 0.000 & 0.025 & 0.050 & 0.075 & 0.100 \\
Raw material moisture & 20.0 & 22.5 & 25.0 & 27.5 & 30.0 \\
$\begin{array}{l}\text { content }(\%) \\
\text { Temperature - zone } 5{ }^{\circ} \mathrm{C}\end{array}$ & 100.0 & 112.5 & 125.0 & 137.5 & 150.0 \\
\hline $\begin{array}{l}{ }^{1} \text { Commercial product containing minimum } \\
\text { containing } 10 \% \text { soy protein; }{ }^{2} \text { commercial product }\end{array}$
\end{tabular}

The EI was obtained by dividing the area of the transversal section of the product by the area of the transversal section of the extruder die. This measurement was carried out with 10 randomly chosen samples of dry extrudates.

Instrumental hardness was evaluated using a TA-XT2 texture analyzer (Stable Micro Systems, UK), with maximum load of $0.10 \mathrm{~N}$, pre-test speed of $4.0 \mathrm{~mm} / \mathrm{s}$, test speed of $1.0 \mathrm{~mm} / \mathrm{s}$, post-test speed of $5.0 \mathrm{~mm} / \mathrm{s}$, distance of $20.0 \mathrm{~mm}$. This measurement was carried out with 10 samples of dry extrudates of $5 \mathrm{~cm}$ length.

Instrumental color was evaluated through the CIELab system, using a Minolta colorimeter (Konica Minolta Sensing Americas, USA), arranging a group of $10 \mathrm{~cm}$ length snacks so as to completely cover the light beam.

\subsection{Statistical analysis}

Statistical evaluation of the results was carried out using the Statistica ${ }^{\circledast}$ program, version 5.5 (StatSoft, Tulsa, OK, USA), to obtain regression coefficients, ANOVA and response surfaces at a $90 \%$ significance level.

\subsection{Sensory analysis and characterization of the chosen products}

A sensory acceptance test was carried out with snack samples produced according to the parameters of 2 essays chosen from the experimental design, considering the highest levels of the functional ingredients and the best expansion and texture characteristics.

The acceptance test was carried out using a structured hedonic scale, with extremes of 1 (disliked extremely) and 9 (liked extremely) to analyze the following attributes: appearance, color, texture, aroma and taste. Purchase intention was also evaluated using a 5-point scale, varying from 1 (would certainly not buy) to 5 (would certainly buy). At the end, the panelists were asked to suggest a flavor for the snacks. Thirty-four nontrained panelists were recruited, characterized as to gender, age and snack consumption frequency.

The best product between these two samples was also characterized as to its expansion index (EI), proximate composition and instrumental hardness, using the methodology described in item 2.5 . 


\section{Results and discussion}

\subsection{Characterization of the raw materials}

The analysis of the particle size distribution of the raw materials (Table 2) showed that the greatest fraction of the particles of corn flour (82.7\%) and SPI (99.8\%) were smaller than $0.250 \mathrm{~mm}$. However, SPI particle size determination using this methodology is not very precise due to the characteristics of the material. As it is very light, soy protein isolate resists the vibration of the equipment and has difficulty in passing through the orifices of the sieves, but, it was possible to visually note that its particles were much smaller than those of the corn flour used in the experiments.

Regarding the proximate composition, corn flour presented 9.60\% moisture, $8.29 \%$ proteins, $0.43 \%$ lipids, $0.85 \%$ ash and $80.83 \%$ carbohydrates. These data are in accordance with the results found by Alvin, Sgarbieri and Chang (2002). SPI presented $4.00 \%$ moisture, 91.50 per cent proteins, $0.28 \%$ lipids, $4.09 \%$ ash and $0.13 \%$ carbohydrates. These data are in accordance with the results found by Martins (2005).

\subsection{Characterization of the extruded products}

The results of the characterization of the extruded products elaborated according to the experimental design are presented in Table 3. The response surface analysis for each of the dependent variables can be seen in items 3.2.1 to 3.2.3.

\section{Expansion index (EI)}

The expansion index (EI) can be described as a mathematical equation (Equation 1), as presented below, to be used with the coded values of the independent variables, within the ranges studied:

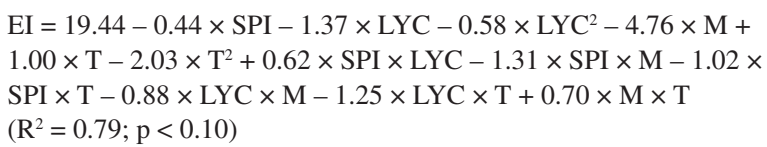

where:

$$
\begin{aligned}
& \text { SPI }=\text { SPI content }(\%) ; \\
& \text { LYC = lycopene preparation content }(\%) ; \\
& \mathrm{M}=\text { raw material moisture content }(\%) ; \text { and } \\
& \mathrm{T} \quad=\text { barrel temperature in zone } 5^{\circ} \mathrm{C} .
\end{aligned}
$$

Table 2. Particle size distribution of the corn flour and soy protein isolate (SPI) used.

\begin{tabular}{lcc}
\hline \multirow{2}{*}{ Sieves $($ mesh and $\mathrm{mm})$} & \multicolumn{2}{c}{ \% retained } \\
\cline { 2 - 3 } & Corn flour & \multicolumn{1}{c}{ SPI } \\
\hline $20(0.840 \mathrm{~mm})$ & 0.05 & 0.01 \\
$35(0.420 \mathrm{~mm})$ & 0.03 & 0.04 \\
$60(0.250 \mathrm{~mm})$ & 17.26 & 0.18 \\
$80(0.177 \mathrm{~mm})$ & 29.86 & 49.33 \\
$100(0.149 \mathrm{~mm})$ & 17.00 & 13.21 \\
Bottom & 35.80 & 37.22 \\
\hline
\end{tabular}

The parameters considered in the equation, obtained using the Statistica ${ }^{\circledast}$ program, are statistically significant $(\mathrm{p}<0.10)$.

Table 4 presents the results of the ANOVA generated through the Statistica ${ }^{\circledast}$ program.

Observing the values obtained in the ANOVA, it can be noted that calculated $\mathrm{F}$ is greater than tabled $\mathrm{F}$ and that the $\mathrm{R}^{2}$ is higher than $70 \%$, thus, the response surfaces were built.

In Figures $1 \mathrm{a}$ and $\mathrm{b}$, the response surfaces for the expansion index (EI) can be seen, with the variation of the independent parameters lycopene and SPI, and raw material moisture content and barrel temperature in zone 5, respectively.

As can be observed in Figure 1a, there was a reduction of the expansion index (EI) with the increase in lycopene and soy protein isolate contents.

According to Figure 1b, a reduction of the expansion index (EI) was noted with the increase in raw material moisture content. Maximum expansion was observed for zone 5 barrel temperatures close to $125^{\circ} \mathrm{C}$.

\section{Instrumental hardness}

For the statistical analysis, the result obtained for one of the central points (Assay $25=44.10 \mathrm{~N}$ ) was not considered, as it differed greatly from the remaining central points.

Instrumental hardness can be described as a mathematical equation (Equation 2), as presented below, to be used with the coded values of the independent variables, within the ranges studied:

Hardness $=13.15-4.32 \times \mathrm{SPI}+3.31 \times \mathrm{SPI}^{2}+3.08 \times \mathrm{LYC}+1.57 \times$

$\mathrm{LYC}^{2}+8.17 \times \mathrm{M}+1.49 \times \mathrm{M}^{2}-11.20 \times \mathrm{T}+4.47 \times \mathrm{T}^{2}+1.55 \times$

$\mathrm{SPI} \times \mathrm{M}+4.31 \times \mathrm{SPI} \times \mathrm{T}-2.17 \times \mathrm{LYC} \times \mathrm{M}-4.56 \times \mathrm{M} \times \mathrm{T}$

$\left(\mathrm{R}^{2}=0.68 ; \mathrm{p}<0.10\right)$

where:

SPI = SPI content (\%);

LYC = lycopene preparation content (\%);

$\mathrm{M}$ = raw material moisture content (\%); and

$\mathrm{T}=$ barrel temperature in zone $5^{\circ} \mathrm{C}$.

The parameters considered in the equation, obtained using the Statistica ${ }^{\circledast}$ program, are statistically significant $(\mathrm{p}<0.10)$.

Table 5 presents the results of the ANOVA generated through the Statistica ${ }^{\circledR}$ program.

Observing the values obtained in the ANOVA, it can be noted that calculated $\mathrm{F}$ is greater than tabled $\mathrm{F}$ and that the $\mathrm{R}^{2}$ is very close to $70 \%$, thus, the response surfaces were built.

In Figures $2 \mathrm{a}$ and $\mathrm{b}$, the response surfaces for hardness can be seen, with the variation of the independent parameters lycopene and SPI, and raw material moisture content and barrel temperature in zone 5 , respectively.

According to Figure $2 a$, it can be observed that SPI contributed to the reduction of the hardness of the extrudates, a fact that can be interesting for their sensory acceptance. A 
Table 3. Results of the characterization of the extruded products.

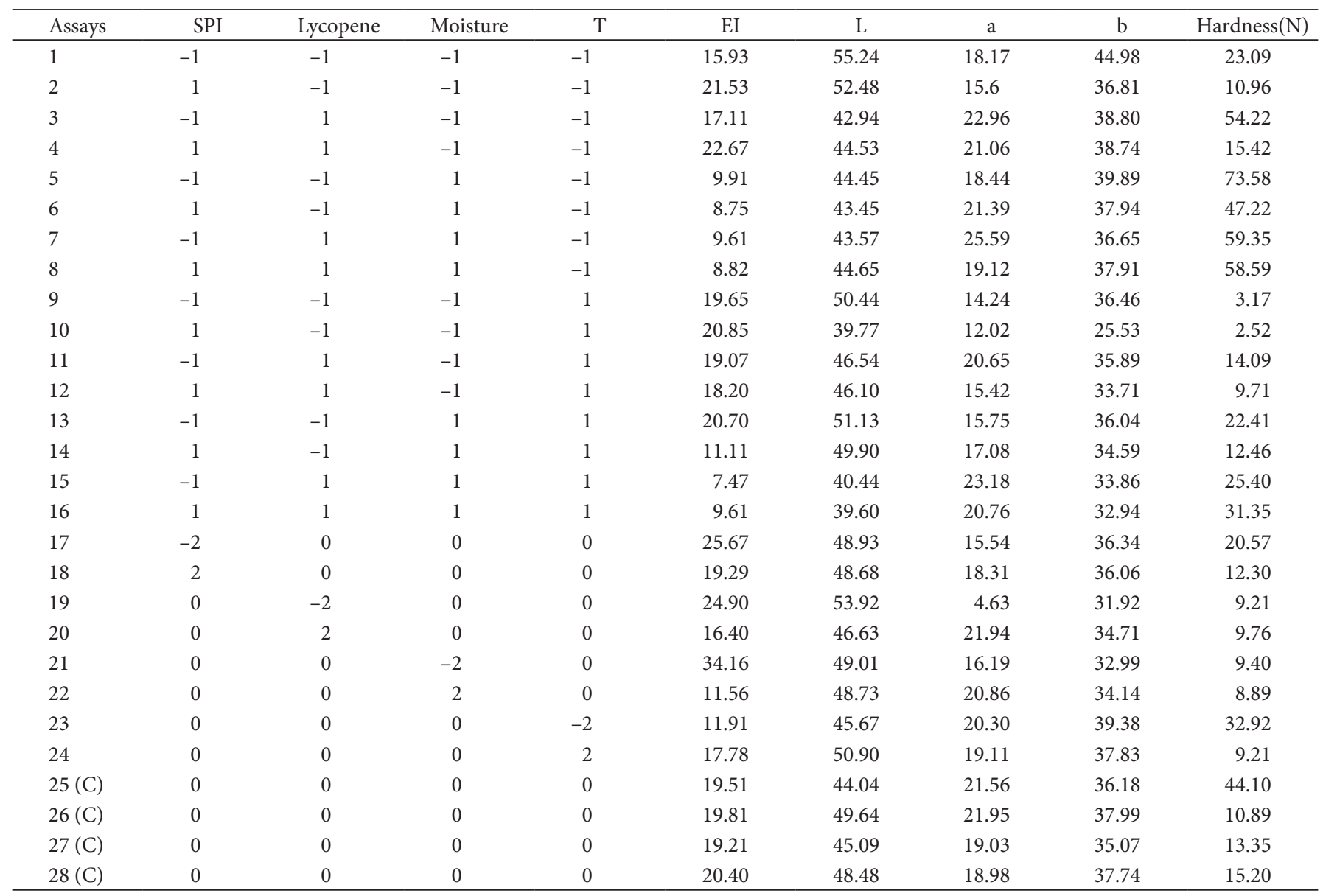

(C): central points.

Table 4. ANOVA for the response expansion index (EI).

\begin{tabular}{lrcccc}
\hline $\begin{array}{c}\text { Source of } \\
\text { variation }\end{array}$ & $\begin{array}{r}\text { Sum of } \\
\text { squares }\end{array}$ & $\begin{array}{c}\text { Degrees of } \\
\text { freedom }\end{array}$ & $\begin{array}{c}\text { Mean } \\
\text { square }\end{array}$ & Fcalc & p-value \\
\hline Regression & 824.69 & 12 & 68.72 & 4.82 & 0.00266 \\
Residues & 213.66 & 15 & 14.24 & & \\
Lack of fit & 212.89 & 12 & 17.74 & 69.12 & 0.00251 \\
Pure error & 0.77 & 3 & 0.26 & & \\
Total & 1038.35 & 27 & 38.46 & - & - \\
$\mathrm{R}^{2}=0.79$ & - & - & - & Ftab & 2.02 \\
\hline
\end{tabular}

minimum hardness region was obtained with SPI values of 15 to $25 \%$ and lycopene preparation from 0 to $0.05 \%$.

According to Figure 2b, a maximum hardness peak can be observed for the combination of high raw material moisture content and low extrusion temperature. However, working with minimum moisture content, a tendency to the increase in hardness with the increase in extrusion temperature above $140^{\circ} \mathrm{C}$ can be observed, determining an optimum range between 112.5 and $140{ }^{\circ} \mathrm{C}$, with $20 \%$ moisture (when the functional ingredients are fixed at the central point).
Comparing Figures $1 \mathrm{~b}$ and $2 \mathrm{~b}$, an inverse behavior can be observed for the expansion index (EI) and instrumental hardness, when considering the process parameters moisture and temperature. As expected, the more expanded products presented lower hardness values.

\section{Instrumental color}

After statistical analysis of the parameters obtained through the instrumental analysis of color, a significant model was obtained only for parameter "a", related to the intensity of red. Lycopene, among other attributes, confers this red color.

Parameter "a" can be described as a mathematical equation (Equation 3), as presented below, to be used with the coded values of the independent variables, within the ranges studied:

Parameter "a" $=19.75+2.94 \times$ LYC $-1.38 \times \mathrm{LYC}^{2}+1.27 \times$

$\mathrm{M}-1.07 \times \mathrm{T}-0.97 \times \mathrm{SPI} \times \mathrm{LYC}\left(\mathrm{R}^{2}=0.75 ; \mathrm{p}<0.10\right)$

where:

$\mathrm{SPI}=\mathrm{SPI}$ content $(\%)$;

LYC = lycopene preparation content (\%); 

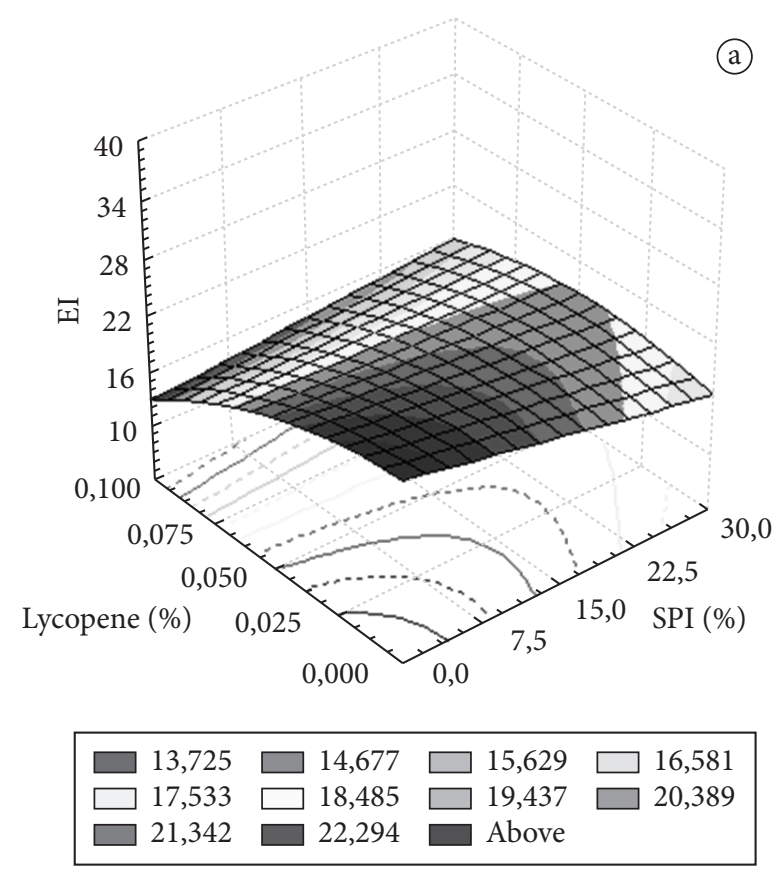

(b)

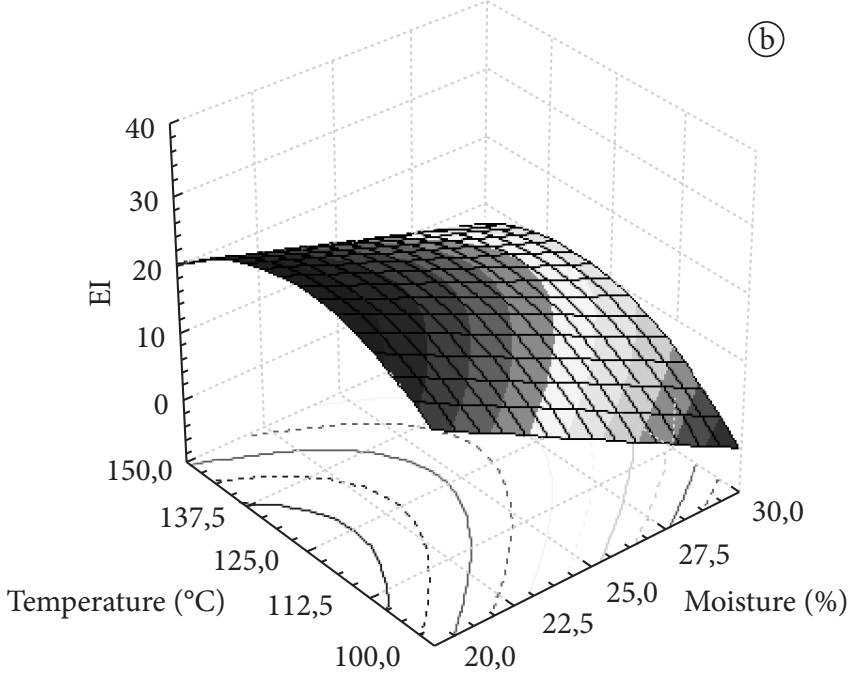

\begin{tabular}{|c|c|c|c|}
\hline$\square-0,120$ & $\square$ 2,788 & $\square$ 5,695 & $\square 8,603$ \\
\hline$\square 11,510$ & $\square 14,418$ & $\square 17,325$ & 20,233 \\
\hline$\square 23,140$ & $\square$ 26,048 & $\square$ Above & \\
\hline
\end{tabular}

Figure 1. a) Response surface for EI varying lycopene (\%) and SPI (\%) contents. The other 2 variables were fixed at the central point; and b) response surface for EI varying moisture (\%) and temperature $\left({ }^{\circ} \mathrm{C}\right)$. The other 2 variables were fixed at the central point.

Table 5. ANOVA for the response hardness.

\begin{tabular}{lccccc}
\hline $\begin{array}{c}\text { Source of } \\
\text { variation }\end{array}$ & $\begin{array}{c}\text { Sum of } \\
\text { squares }\end{array}$ & $\begin{array}{c}\text { Degrees of } \\
\text { freedom }\end{array}$ & $\begin{array}{c}\text { Mean } \\
\text { square }\end{array}$ & Fcalc & p-value \\
\hline Regression & 6543.97 & 12 & 545.33 & 2.83 & 0.02711 \\
Residues & 3079.52 & 16 & 192.47 & & \\
Lack of fit & 3070.17 & 12 & 255.85 & 54.73 & 0.01808 \\
Pure error & 9.35 & 2 & 4.68 & & \\
Total & 9623.49 & 26 & 370.13 & - & - \\
$\mathrm{R}^{2}=0.68$ & - & - & - & Ftab & 1.99 \\
\hline
\end{tabular}
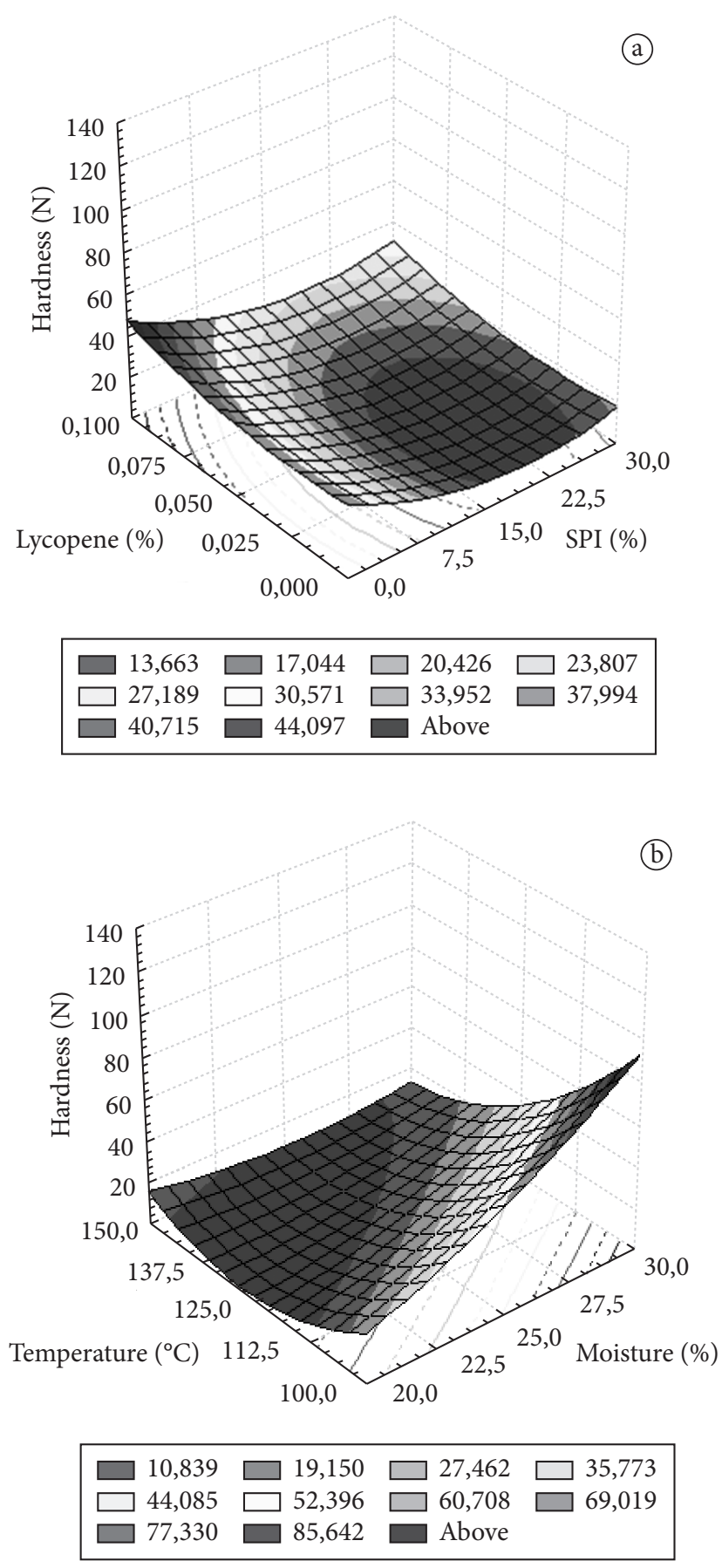

Figure 2. a) Response surface for instrumental hardness varying lycopene (\%) and SPI (\%) contents. The other 2 variables were fixed at the central point; and b) Response surface for instrumental hardness varying moisture $(\%)$ and temperature $\left({ }^{\circ} \mathrm{C}\right)$. The other 2 variables were fixed at the central point.

$$
\begin{aligned}
& \mathrm{M}=\text { raw material moisture content (\%); and } \\
& \mathrm{T}=\text { barrel temperature in zone } 5^{\circ} \mathrm{C} \text {. }
\end{aligned}
$$

The parameters considered in the equation, obtained using the Statistica ${ }^{\oplus r o g r a m}$, are statistically significant $(\mathrm{p}<0.10)$. 
Table 6 presents the results of the ANOVA generated through the Statistica ${ }^{\circ}$ program.

Observing the values obtained in the ANOVA, it can be noted that calculated $\mathrm{F}$ is greater than tabled $\mathrm{F}$ and that the $\mathrm{R}^{2}$ is higher than $70 \%$, thus, the response surfaces were built.

In Figures $3 a$ and $b$, the response surfaces for the parameter "a" can be seen, with the variation of the independent parameters lycopene and SPI, and raw material moisture content and barrel temperature in zone 5 , respectively.

It can be observed, in Figure 3a, that the intensity of the color red of the products increased with the increase in the level of lycopene. On the other hand, SPI showed little effect.

According to Figure $3 \mathrm{~b}$, an increase in the intensity of red occurred with the increase in raw material moisture content and with the reduction of barrel temperature in zone 5 . The greatest intensity of red was obtained at $30 \%$ raw material moisture content and $100{ }^{\circ} \mathrm{C}$ in zone 5 of the extruder, and may be due to the low expansion of the snacks in these conditions, leading to a concentration of lycopene in a smaller area of the product. In more drastic conditions, lycopene degradation may have occurred. Also, according to Ferreira (2006), high temperatures affect the structure and the color of the surface of the extrudates that becomes flaky and whiter.

\subsection{Sensory analysis and characterization of the chosen product}

To choose the products to be subjected to sensory analysis, the following criteria were considered:

- Maximum levels of lycopene and soy protein isolate, focusing on the functional properties of the product;

- Raw material moisture content: $20 \%$, which resulted in a product with a higher expansion index (EI) and lower instrumental hardness; and

- Temperatures: of 125 and $137^{\circ} \mathrm{C}$, aiming at a product with lower hardness. In the surfaces generated with lycopene and SPI at their maximum levels $(+2)$, an increase in hardness was observed with the increase in temperature from 125 to $137^{\circ} \mathrm{C}$. These 2 assays were subjected to sensory analysis to confirm the theoretical results.

Table 6. ANOVA for the response parameter "a".

\begin{tabular}{lccrcc}
\hline $\begin{array}{c}\text { Source of } \\
\text { variation }\end{array}$ & $\begin{array}{c}\text { Sum of } \\
\text { squares }\end{array}$ & $\begin{array}{c}\text { Degrees of } \\
\text { freedom }\end{array}$ & $\begin{array}{c}\text { Mean } \\
\text { square }\end{array}$ & Fcalc & p-value \\
\hline Regression & 341.55 & 5 & 68.31 & 13.37 & $<0.00001$ \\
Residues & 112.44 & 22 & 5.11 & & \\
Lack of fit & 104.8 & 19 & 5.52 & 2.17 & 0.28770 \\
Pure error & 7.64 & 3 & 2.55 & & \\
Total & 453.99 & 27 & 16.81 & - & - \\
$\mathrm{R}^{2}=0.75$ & - & - & - & Ftab & 2.13 \\
\hline
\end{tabular}

\section{Profile of the panelists}

Of the 34 untrained panelists recruited for the sensory analysis, $73.5 \%$ were female, with ages varying between 17 and 41; and $26.5 \%$ were male, with ages varying between 21 and 38. The panelists presented the snack consumption frequency profile shown in Figure 4.
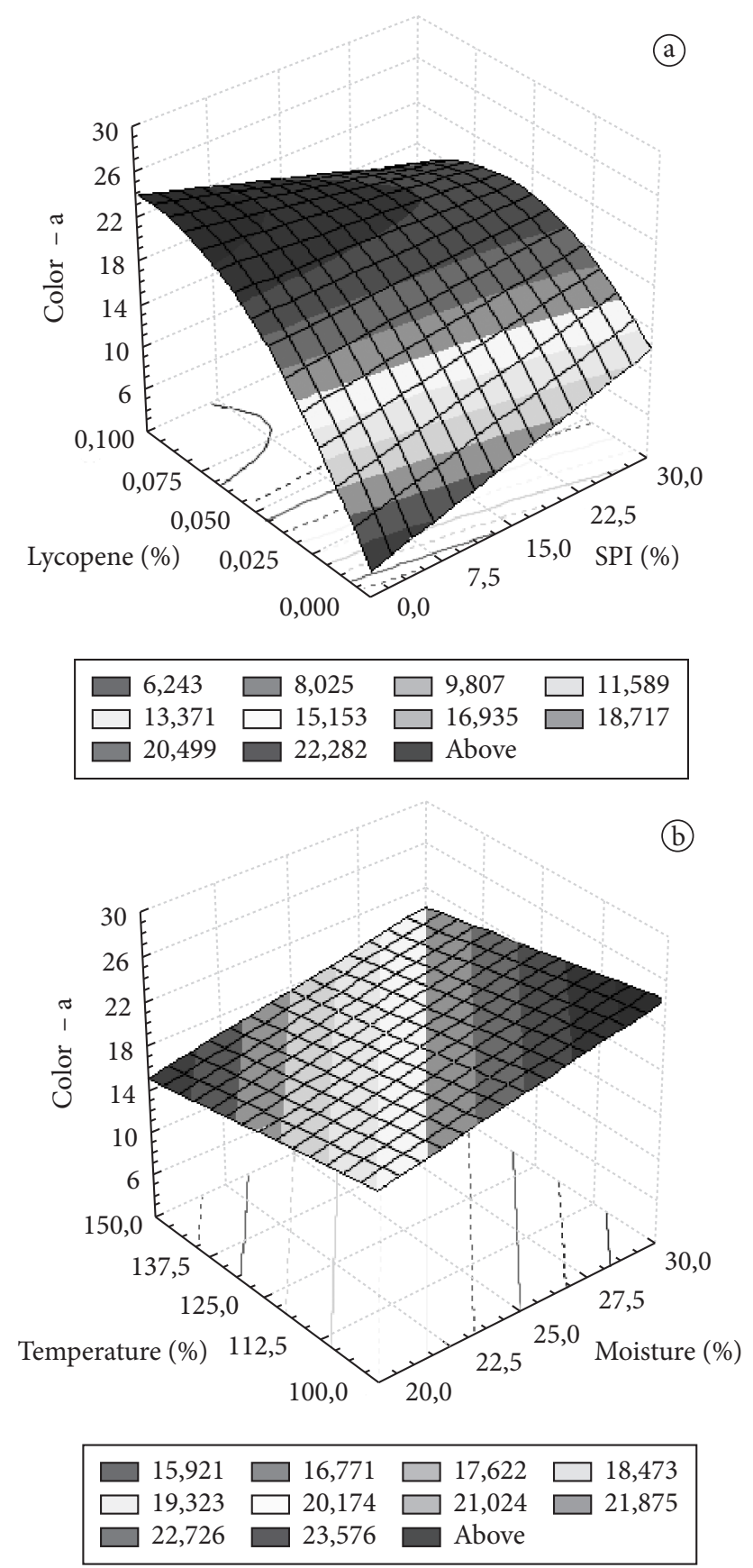

Figure 3. a) Response surface for parameter "a" varying lycopene (\%) and SPI (\%) contents. The other 2 variables were fixed at the central point; and b) Response surface for parameter "a" varying moisture (\%) and temperature $\left({ }^{\circ} \mathrm{C}\right)$. The other 2 variables were fixed at the central point. 


\section{Sensory acceptance}

The products subjected to sensory analysis can be visualized in Figure 5.

The results of the sensory acceptance test for the products extruded at 125 (sample A) and $137^{\circ} \mathrm{C}$ (sample B) can be seen in Table 7.

For the attributes aroma and texture, a greater acceptance of the snacks extruded at $125^{\circ} \mathrm{C}$ (sample A) was observed, when

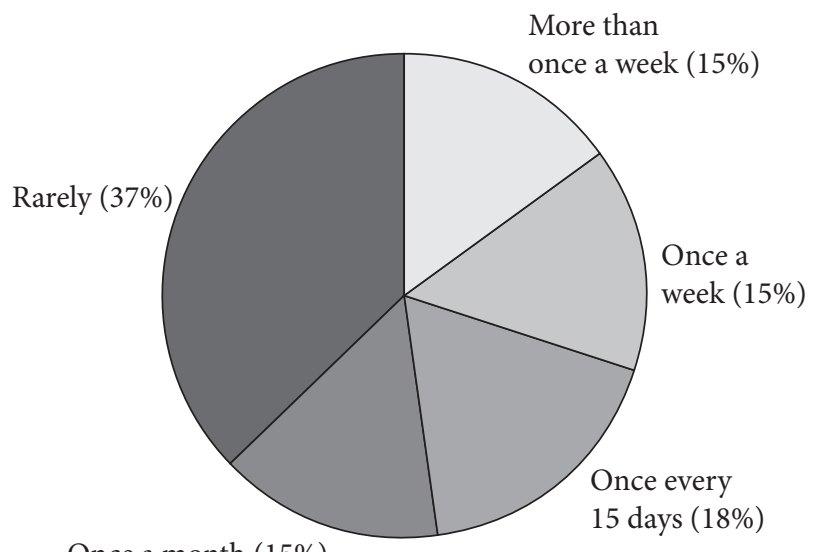

Once a month (15\%)

Figure 4. Snack consumption frequency of the panelists.

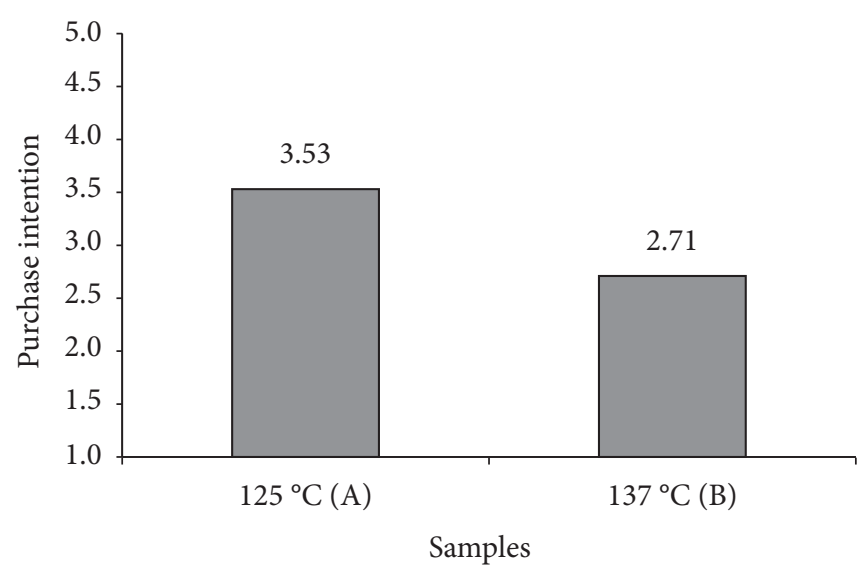

Figure 5. Products extruded at 125 (sample A) and $137^{\circ} \mathrm{C}$ (sample B), subjected to sensory analysis.

Table 7. Sensory acceptance of the snacks extruded at 125 (sample A) and $137^{\circ} \mathrm{C}$ (sample B).

\begin{tabular}{ccrrrr}
\hline Samples & Appearance & Color & Aroma & Texture & Taste \\
\hline A & $5.62^{\mathrm{a}}$ & $6.74^{\mathrm{a}}$ & $6.15^{\mathrm{a}}$ & $7.01^{\mathrm{a}}$ & $5.74^{\mathrm{a}}$ \\
B & $5.74^{\mathrm{a}}$ & $6.65^{\mathrm{a}}$ & $5.00^{\mathrm{b}}$ & $5.41^{\mathrm{b}}$ & $4.94^{\mathrm{a}}$ \\
\hline
\end{tabular}

Scores varying from $1=$ disliked extremely to $9=$ liked extremely. Identical letters in the column indicate that there is no significant difference at $\mathrm{p}<0.05$. compared to the products elaborated at $137^{\circ} \mathrm{C}$ (sample B). Thus, a better texture for the product extruded at $125^{\circ} \mathrm{C}$ was confirmed, as expected from the analysis of the surface shown in Figure 2b.

For sample A, extruded at $125^{\circ} \mathrm{C}$, the mean score attributed by the panelists is situated between the options "would probably buy/would probably not buy" and "would possibly buy" (3.53), while for sample $\mathrm{B}$, extruded at $137^{\circ} \mathrm{C}$, the mean score attributed by the panelists is situated between the options "would possibly not buy" and "would probably buy/would probably not buy" (2.71), indicating that sample A received a more positive evaluation.

The results of the sensory analysis presented refer to the evaluation of the products in the form of a base-formulation for snacks (not flavored). During the trial, panelists were asked to suggest possible flavors for the product. The most frequently suggested flavors were cheese (17 panelists) and pizza (10 panelists). Other flavors were also suggested, such as tomato (5 panelists), bacon (5 panelists), ham (4 panelists), pepper ( 2 panelists) and onion (1 panelist).

\section{Characterization of the chosen product}

The product extruded at $125^{\circ} \mathrm{C}$ presented an expansion index (EI) of 24.16. Its proximate composition was: 8.23 per cent moisture, $37.19 \%$ proteins, $0.34 \%$ lipids, 1.43 per cent ash and $52.81 \%$ carbohydrates.

\section{Conclusions}

In general, a reduction in expansion was observed with the addition of lycopene and soy protein isolate (SPI), but the increase in SPI content reduced instrumental hardness. Instrumental hardness was also lower for lower moisture contents and temperatures around $125{ }^{\circ} \mathrm{C}$ (where greatest expansion was observed).

Red color intensity increased with the increase in lycopene content, and decreased with the reduction of moisture content and with the increase in temperature (factors that favor expansion and probably also lycopene degradation).

It was possible to elaborate a base-formulation for functional snacks, with a good sensory acceptance, using 30\% SPI, $0.100 \%$ lycopene preparation, $20 \%$ raw material moisture content and $125^{\circ} \mathrm{C}$ in zone 5 of the extruder. This product would contain approximately $27 \%$ of the RDI for soybean protein and $38 \%$ of the RDI for lycopene, if we consider that there is no degradation of these compounds during extrusion. In this combination of SPI and lycopene contents, the formulated snacks can be characterized as a soybean protein source and rich in lycopene (ANVISA, 2008).

Future studies may be carried out using cheese and pizza flavors to verify the acceptance of the flavored product. Apart from this, it would be interesting to determine the residual quantity of lycopene, to verify if degradation does or does not occur during the process, and to evaluate the shelf-life of the product. New trials may also be carried out further reducing raw material moisture content to determine maximum expansion 
points of the corn-based snacks, since it can be observed that, for moisture contents below 20\%, higher expansion indexes might be obtained.

\section{Acknowlegements}

We would like to thank BAPTISTELLA, BASF and SOLAE for donating the corn flour, lycopene and soy protein isolate used in this study, respectively.

\section{References}

ALVES, R. M. L.; GROSSMANN, M. V. E. Parâmetros de extrusão para produção de "snacks" de farinha de cará (Dioscorea alata). Ciência e Tecnologia de Alimentos, v. 22, n. 1, p. 32-38, 2002.

ALVIN, I. D.; SGARBIERI, V. C.; CHANG, Y. K. Desenvolvimento de farinhas mistas extrusadas à base de farinha de milho, derivados de levedura e caseína. Ciência e Tecnologia de Alimentos, v. 22, n. 2, p. 170-176, 2002.

AMERICAN ASSOCIATION OF CEREAL CHEMISTS - AACC. Approved methods of the AACC. 8 ed. St. Paul, 1983. (v. 1 e 2)

AMERICAN ORGANIZATION OF ANALYTICAL CHEMISTS AOAC. Official methods of analysis of the AOAC International. 16 ed. Gaithersburg, 1995.

AGÊNCIA NACIONAL DE VIGILÂNCIA SANITÁRIA - ANVISA. Alimentos com alegações de propriedades funcionais e ou de saúde, novos alimentos/ingredientes, substâncias bioativas e probióticos. Brasília, 2008. Disponível em: <http://www.anvisa.gov.br/alimentos/ comissoes/tecno_lista_alega.htm>. Acesso em: 03 fev. 2010.

AGÊNCIA NACIONAL DE VIGILÂNCIA SANITÁRIA - ANVISA. Portaria n. 31, de 13 de janeiro de 1998. Aprova o regulamento técnico referente a alimentos adicionados de nutrientes essenciais, constante do anexo desta Portaria. Diário Oficial da União, Poder Executivo, Brasília, DF, 16 de janeiro de 1998. Disponível em:<http:// http://e-legis.anvisa.gov.br/leisref/public/showAct. php?id=64\&word=> . Acesso em: 20 abr. 2006.

AGÊNCIA NACIONAL DE VIGILÂNCIA SANITÁRIA - ANVISA. Resolução RDC n. 359, de 23 de dezembro de 2003. Aprova regulamento técnico de porções de alimentos embalados para fins de rotulagem nutricional. Diário Oficial da União, Poder Executivo, Brasília, DF, 26 de dezembro de 2003. Disponível em: <http://www.anvisa.gov.br/legis/resol/2003/rdc/359_03rdc.pdf >. Acesso em: 09 jul. 2006.

ATHAR, N. et al. Vitamin retention in extruded food products. Journal of Food Composition and Analysis, v. 19, n. 4, p. 379-383, 2006.

BOMBO, A. J. Obtenção e caracterização nutricional de snacks de milho (Zea mays L.) e linhaça (Linum usitatissimum L.). 2006. 96 p. Dissertação (Mestrado em Saúde Pública) - Universidade de São Paulo - USP, São Paulo.

DESROCHES, S. et al. Soy protein favorably affected LDL size independently of isoflavones in hypercholesterolemic men and women. Journal of Nutrition, v. 134, n. 3, p. 574-579, 2004.

FERREIRA, R. E. Avaliação de parâmetros do processo de extrusão e do teor de farelo de trigo adicionado em características de "snacks" expandidos de milho. 2006. 163 p. Dissertação (Mestrado em Tecnologia de Alimentos) - Universidade Estadual de Campinas - UNICAMP, Campinas.

FOOD AND DRUG ADMINISTRATION - FDA. Soy: health claims for soy protein, questions about other components. Rockville, MD, 2000. Disponível em: <http://www.fda.gov/fdac/features/2000/300_ soy.html>. Acesso em: 15 mai. 2006.
GANN, P. H. et al. Lower prostate cancer risk in men with elevated plasma lycopene levels: results of a prospective analysis. Cancer Research, v. 59, mar., p. 1225-1230, 1999.

GIOVANNUCCI, E. et al. Intake of carotenoids and retinol in relation to risk of prostate cancer. Journal of the National Cancer Institute, v. 87, n. 23, p. 1767-1776, 1995.

GOULA, A. M. et al. Prediction of lycopene degradation during a drying process of tomato pulp. Journal of Food Engineering, v. 74, n. 1, p. 37-46, 2006.

HUANG, R. C. et al. The study of optimum operating conditions of extruded snack food with tomato powder. Journal of Food Process Engineering, v. 29, n. 1, p. 1-21, 2006.

IBANOGLU, S. et al. Physical and sensory evaluation of a nutritionally balanced gluten-free extruded snack. Journal of Food Engineering, v. 75, n. 4, p. 469-472, 2006.

JAMORA, J. J.; RHEE, K. S.; RHEE, K. C. Chemical and sensory properties of expanded extrudates from pork meat-defatted soy flour blends with onion, carrot and oat. Journal of Food Science and Nutrition, v. 6, n. 3, p. 158-162, 2001.

KARAM, L. B. Z.; GROSSMANN, M. V. E.; SILVA, R. S. S. F. Misturas de farinha de aveia e amido de milho com alto teor de amilopectina para produção de "snacks". Ciência e Tecnologia de Alimentos, v. 21, n. 2, p. 158-163, 2001.

LAUNAY, B.; LISCH, J. M. Twin-screw extrusion cooking of starches: flow behavior of starch pastes, expansion and mechanical properties of extrudates. Journal of Food Engineering, v. 2, n. 4, p. 259-280, 1983.

LEE, K. A.; BRENNAND, C. P. Physico-chemical, textural and sensory properties of a fried cookie system containing soy protein isolate. International Journal of Food Science and Technology, v. 40, n. 5, p. 501-508, 2005.

LI, S .Q. et al. Textural modification of soy bean/corn extrudates as affected by moisture content, screw speed and soy bean concentration. International Journal of Food Science and Technology, v. 40, n. 7, p. 731-741, 2005.

LOVATI, M. R.; MANZONI, C.; GIANAZZA, E. Soy protein peptides regulate cholesterol homeostasis in Hep G2 cells. Journal of Nutrition, v. 130, n. 10, p. 2543-2549, 2000.

MARTINS, M. T. S. Caracterização química e nutricional de plasteína produzida a partir de hidrolisado pancreático de isolado protéico de soja. Ciência e Tecnologia de Alimentos, v. 25, n. 4, p. 683-690, 2005.

NWABUEZE, T. U. Effect of process variables on trypsin inhibitor activity (TIA), phytic acid and tannin content of extruded African breadfruit-corn-soy mixtures: a response surface analysis. Lebensmittel Wissenschaft und Technologie, v. 40, n. 1, p. 21-29, 2007.

REID, R. Hot and fruity: the future for snack flavours. Food Reviews, v. 25, n. 1, p. 15-21, 1998.

TAHNOVEN, R. et al. Black currant seeds as a nutrient source in breakfast cereals produced by extrusion cooking. Lebensmittel Untersuchung Forschung, v. 206, n. 5, p. 360-363, 1998.

THYMI, S. et al. Structural properties of extruded corn starch. Journal of Food Engineering, v. 68, n. 4, p. 519-526, 2005.

VERÔNICA, A. O.; OLUSOLA, O. O.; ADEBOWALE, E. A. Qualities of extruded puffed snacks from maize/soybean mixture. Journal of Food Process Engineering, v. 29, n. 2, p. 149-161, 2006.

WAGNER, L. R. Some like it hot... and some like it hotter. Snack World, v. 1, p. 38-40, 1989.

WHITE, G. Defining the true meaning of snacks. Food Technology International - Europe, v. 2, n. 7, p. 115-117, 1994. 